\title{
The clinical potential of microRNAs
}

\author{
Anuradha Budhu*, Junfang Ji, Xin W Wang
}

\begin{abstract}
MicroRNAs are small noncoding RNAs that function to control gene expression. These small RNAs have been shown to contribute to the control of cell growth, differentiation and apoptosis, important features related to cancer development and progression. In fact, recent studies have shown the utility of microRNAs as cancer-related biomarkers. This is due to the finding that microRNAs display altered expression profiles in cancers versus normal tissue. In addition, microRNAs have been associated with cancer progression. In this review, the mechanisms to alter microRNA expression and their relation to cancer will be addressed. Moreover, the potential application of microRNAs in clinical settings will also be highlighted. Finally, the challenges regarding the translation of research involving microRNAs to the clinical realm will be discussed.
\end{abstract}

\section{Review}

The Biogenesis and Physiological Functions of MicroRNAs MicroRNAs are a group of small noncoding functional RNAs that are approximately 22 nucleotides in length [1]. MicroRNAs are transcribed by RNA polymerase II or III as longer primary microRNAs termed pri-microRNA. This molecule is then modified in the nucleus through capping and polyadenylation and subsequently cleaved into smaller segments by Drosha, an RNAseIII enzyme. This forms a hairpin precursor of approximately 60-70 nucleotides, termed pre-microRNA, which is exported to the cytoplasm and modified by another enzyme, the RNAseII endonuclease, Dicer, to form a duplex of mature microRNA. One of the microRNA strands of the duplex is loaded onto the RNA-induced silencing complex (RISC) where it is then able to either cleave RNA targets or repress protein translation dependent upon its complementarity to the target mRNA. Through their binding to target mRNA sequences, microRNAs have a large number of biologically diverse functions. They have the capacity to control the expression of many downstream genes which can affect several cell regulatory pathways, such as cell growth, differentiation, mobility and apoptosis.

\section{The Detection of MicroRNA Expression}

Several techniques have been developed to examine microRNA expression. One of the most predominant methods in the literature is microRNA microarrays.

\footnotetext{
* Correspondence: budhua@mail.nih.gov

Liver Carcinogenesis Section, Laboratory of Human Carcinogenesis, Center for Cancer Research, National Cancer Institute, Bethesda, MD, USA
}

Microarray technology offers a powerful high-throughput tool to monitor the expression of thousands of microRNAs at once [2]. Quantitative reverse transcriptionpolymerase chain reaction (qRT-PCR) is another reliable and highly sensitive technique for microRNA detection, which is simple and robust, and only requires very small amounts of input total RNA [3]. Standard northern blotting has also been employed to detect and validate microRNA expression levels [4]. In addition, techniques are available to detect microRNAs by in situ hybridization. Although various microRNAs have been detected from tissue sources, these methods require invasive techniques to collect the starting material. Therefore, procedures have also been established to measure microRNA expression in blood products to enable clinical feasibility of microRNA measurement [5]. Most recently, the advent of next generation sequencing technologies allows for the measurement of the absolute abundance as well as the discovery of novel microRNAs. These various techniques have allowed researchers to measure the levels of many microRNAs and determine how alterations in their expression level are associated with particular phenotypes and how they can be clinically utilized. These aspects of microRNA expression levels are discussed in the remainder of this review.

\section{The Role of MicroRNAs in Cancer}

Since their discovery in nematodes, microRNAs have been shown to play a role in cancer (Table 1). The expression patterns, function and regulation of microRNAs in normal and neoplastic human cells are largely 
Table 1 MicroRNAs Associated with Cancer

\begin{tabular}{|c|c|c|c|}
\hline Cancer Type & Human microRNA & Potential Function & References \\
\hline Breast Cancer & $\begin{array}{l}\text { miR-21, miR-125b; } \\
\text { miR126, miR-206, miR-335 }\end{array}$ & $\begin{array}{l}\text { OncomiR; Metastasis } \\
\text { Suppressor }\end{array}$ & {$[49,75,76]$} \\
\hline Colon Cancer & miR-21; miR-34a & $\begin{array}{l}\text { OncomiR; Tumor } \\
\text { Suppressor }\end{array}$ & {$[41,77-79]$} \\
\hline Lung Cancer & $\begin{array}{l}\text { miR-21, miR17-92 cluster, miR-106b/93/25 cluster; } \\
\text { Let-7a, miR-143, miR-145 }\end{array}$ & $\begin{array}{l}\text { OncomiR; Tumor } \\
\text { Suppressor }\end{array}$ & {$[13,40,80,81]$} \\
\hline Pancreatic Cancer & miR-196a, miR196b & OncomiR & {$[82-84]$} \\
\hline Prostate Cancer & $\begin{array}{l}\text { miR-21, miR-15/16; miR-145, } \\
\text { miR-146, miR-330, miR-205 }\end{array}$ & $\begin{array}{l}\text { OncomiR; Tumor } \\
\text { Suppressor }\end{array}$ & {$[69,85,86]$} \\
\hline Ovarian Cancer & $\begin{array}{l}\mathrm{miR}-141, \mathrm{miR}-200 \mathrm{a} / \mathrm{b} / \mathrm{c} ; \\
\mathrm{miR}-199 \mathrm{a} / \mathrm{b}, \mathrm{miR}-140, \mathrm{miR}-145, \mathrm{miR}-204, \mathrm{miR}-125 \mathrm{a} / \mathrm{b}\end{array}$ & $\begin{array}{l}\text { OncomiR; Tumor } \\
\text { Suppressor }\end{array}$ & {$[87,88]$} \\
\hline $\begin{array}{l}\text { Hepatocellular } \\
\text { Carcinoma }\end{array}$ & $\begin{array}{l}\text { miR-21, miR-224, miR-34a, miR221, miR-222, miR-106, miR-303; miR26a/b, let-7g, miR- } \\
\text { 122, miR-422b, miR-145, miR-199 }\end{array}$ & $\begin{array}{l}\text { OncomiR; Tumor } \\
\text { Suppressor; Metastasis }\end{array}$ & {$[46,52,53,89,90]$} \\
\hline Thyroid Cancer & $\begin{array}{l}\text { miR-146, miR-221, miR-222, } \\
\text { miR-181b, miR-155, miR-224 }\end{array}$ & OncomiR & {$[91-93]$} \\
\hline
\end{tabular}

unknown but emerging data and their frequent location at fragile sites, common break-points or regions of amplification or loss of heterozygosity reveal that they may play significant roles in human carcinogenesis. Other possible mechanisms of altered microRNA expression include defective microRNA processing or post-transcriptional regulation, germ-line or somatic mutation and epigenetic changes such as methylation [6-9]. The abnormal expression of several microRNAs have been observed in Burkitt's lymphomas, B cell chronic lymphocytic leukemia (CLL) and in many solid cancer types, including breast, liver, lung, ovarian, cervical, colorectal and prostate [10-21]. Functional analysis has revealed the downregulation of PTEN by miR-21, the tumor suppressor function of the let-7 family and the oncogenic function of the miR17-92 cluster [22-24]. The biological and clinical relevance of microRNA expression patterns have been established in human $\mathrm{B}$ cell CLL and solid tumors, including breast cancers $[11,15,25]$.

Each microRNA has the distinct capability to potentially regulate the expression of hundreds of coding genes and thereby modulate several cellular pathways including proliferation, apoptosis and stress response [26]. Their altered expression in cancer can be a causative factor or perhaps a consequence of the disease state. Dependent upon the nature of their target gene(s), microRNAs may function as tumor suppressors by downregulating target oncogenes (e.g. let-7 g, miR-15/16 and miR-34) or as oncogenes by negatively controlling genes that regulate tumor cell differentiation and apoptosis (e.g. miR-155 and miR-21) [27]. Alternatively, changes in microRNA expression may be a downstream effect of potent oncogenes or tumor suppressors in the carcinogenesis process such as the modulation of miR34 by p53 [28]. MicroRNAs have also been shown to play a role in cancer progression through the modulation of cellular adhesion, cell matrix and signaling activities [29-33]. In addition, microRNAs play roles in regulating the expression of hypoxia-related genes, vascular endothelial growth factors [34-36].

\section{The Clinical Applications of MicroRNAs}

Since the expression of microRNAs are altered in cancers, it is thought that they may function as suitable biomarkers for disease state and progression. Recent studies indicate that expression profiling of microRNAs is a superior method for cancer subtype classification and prognostication $[10,11,20]$. The application of microRNA screening for the purposes of diagnosis and prognosis are briefly described below.

\section{Diagnostic MicroRNAs}

Multiple reports have noted the utility of microRNAs for the diagnosis of cancer $[37,38]$. microRNA expression profiles have been used to distinguish tumor from normal samples, identification of tissue of origin for tumors of unknown origin or in poorly differentiated tumors and to distinguish different subtypes of tumors. Sample datasets have been stratified to show that certain alterations of microRNAs occur in patients at an early stage of cancer and thus may be quite useful for early detection. Large tissue specimens are not needed for accurate MicroRNA detection since their expression can be easily measured in biopsy specimens. Although the majority of these studies have used tissue to assess microRNA levels, recent studies have shown that microRNAs can be measured in formalin fixed paraffin embedded (FFPE) tissues [39]. Given the invasive nature of fresh/frozen tissue collection and the availability of FFPE, this serves as a major advance in the feasibility of measuring microRNA levels for the purposes of diagnosis. Recent studies have also shown that microRNAs can 
be detected in serum. These studies offer the promise of utilizing microRNA screening via less invasive bloodbased mechanisms. In addition, mature microRNAs are relatively stable. These phenomena make microRNAs superior molecular markers and targets for interrogation and as such, microRNA expression profiling can be utilized as a tool for cancer diagnosis $[10,40]$.

\section{Prognostic MicroRNAs}

The potential clinical utility of microRNA extends beyond the realm of diagnosis to other important clinical measures such as prognosis and treatment response. A series of publications has shown that microRNAs are useful indicators of clinical outcome in a number of cancer types [10,40-45]. In addition, microRNAs have been shown to play a predictive role in determining the tendency for recurrence and metastasis [46-50]. These microRNA alterations have not only been found in tumor specimens, but have also been observed in surrounding non-cancerous tissue, indicating that microRNAs may also serve to detect alterations in the cancer microenvironment $[45,51,52]$. microRNAs have also been shown as useful indicators of which patient groups may respond better to a particular treatment regimen. An example of this was shown for liver cancer patients, whereby miR-26 expression could be used to stratify patients for IFN treatment [53]. The full potential of microRNAs as prognostic factors awaits the results of larger prospective studies.

\section{The Therapeutic Application of MicroRNAs}

As noted above, several microRNAs have been shown to be altered in disease states when compared to normal specimens. Whether this differential expression occurs as a consequence of the pathological state or whether the disease is a direct cause of this differential expression is currently unknown. Nonetheless, since microRNAs are deregulated in cancer, it is thought that normalization of their expression could be a potential method of intervention. In this vein, several therapeutic mechanisms have been put forth and are described below (Table 2).

\section{Strategies for microRNA reduction}

The rules of Watson and Crick base-pairing guide the binding of microRNAs to their target sites. In order to circumvent this interaction, anti-microRNA oligonucleotides
(AMOs) have been generated to directly compete with endogenous microRNAs [54]. However, the ability of AMOs to specifically inactivate endogenous targets has been shown to be quite inefficient. Thus, several modifications of AMOs have been generated to improve their effectiveness and stability such as the addition of 2'-Omethyl and 2'-O-methoxyethyl groups to the 5' end of the molecule [55]. Studies have shown that targeting of miR21 , a microRNA that is overexpressed in many cancer types, by such methods effectively reduced tumor size in a xenograft mouse model based on MCF-7 cells [56]. AMOs conjugated to cholesterol (antagomirs) have been also been generated and have been described to efficiently inhibit microRNA activity in-vivo [57]. In addition, lockednucleic-acid antisense oligonucleotides (LNAs) have been designed to increase stability and have been shown to be highly aqueous and exhibit low toxicity in-vivo [58]. In gliomas, this method has been effectively used to completely eradicate miR-21 [59]. Another method for reducing the interaction between microRNAs and their targets is the use of microRNA sponges. These sponges are synthetic mRNAs that contain multiple binding sites for an endogenous microRNA. Sponges designed with multimeric seed sequences have been shown to effectively repress microRNA families sharing the same seed sequence [60]. Although microRNA sponges perform as well as chemically modified AMOs in-vitro, their efficacy in-vivo remains to be determined.

Although these oligonucleotide-based methods have been shown to work, they do elicit off-target side effects and unwanted toxicity. This is due to the capability of microRNAs to regulate hundreds of genes. A strategy called miR-masking is an alternative strategy designed to combat this effect. This method utilizes a sequence with perfect complementarity to the target gene such that duplexing will occur with higher affinity than that between the target gene and its endogenous microRNA. The caveat of this approach is that the choice of target gene must be specific in order to effectively reduce the interaction. This gene-specific, microRNA interfering strategy has been shown to reduce the activities of miR-1, miR-133 and miR-430 in several model systems [61,62]. Another strategy to increase specificity of effects is the use of small

Table 2 Strategies to Employ MicroRNAs in the Clinic

\begin{tabular}{llll}
\hline Strategy & Modulator & Delivery & Clinical Utility \\
\hline Inhibition of mature microRNA cluster & microRNA sponge & Sponge plasmid vector & Silence oncomiR cluster \\
\hline Inhibition of mature microRNA & 2'OME-AMOs & RNA-Liposome Complex & Silence OncomiR \\
\hline Inhibition of mature microRNA & 2'MOE AMOs & Oligonucleotide-Liposome Complex & Silence OncomiR \\
\hline Inhibition of pri-microRNA & AMOs & Oligonucleotide-Liposome Complex & Silence miR cluster \\
\hline Inhibition of mature microRNA & LNA-antagomiR & Unconjugated & Silence OncomiR \\
\hline Silence selected target & Synthetic microRNAs & Conjugation & [97,98] \\
\hline
\end{tabular}


molecule inhibitors against specific microRNAs. Azobenzene, for example, has been identified as a specific and efficient inhibitor of miR-21 [63]. Although the effectiveness of such inhibitors awaits exploration in-vivo, they are potentially promising tools for cancer therapy.

\section{Strategies to overexpress microRNAs}

Elevating the expression of microRNAs with tumor suppressive roles is a strategy to restore tumor inhibitory functions in the cell. This can be achieved through the use of viral or liposomal delivery mechanisms [64,65]. Several microRNAs have been introduced to cells via this methodology, including miR-34, miR-15, miR-16 and let-7 [66-69]. Systemic administration of miR-26, a tumor suppressive microRNA in HCC, using adenovirus-associated virus (AAV) in an animal model of HCC, results in inhibition of cell proliferation and tumor-specific apoptosis [70]. This approach reduces toxicity since AAV vectors do not integrate into the host genome and eventually are eliminated. Although viral vector-directed methods show high gene transfer efficiency, they lack tumor targeting and residual viral elements can elicit immunonogenic effects. This has led to the development of non-viral methods of gene transfer such as cationic liposome mediated systems. These lipoplexes are promising, but they lack tumor specificity and have relatively low transfection efficiency when compared to viral vectors.

MicroRNA mimics have also been used to increase microRNA expression. These small, chemically modified double-stranded RNA molecules mimic endogenous mature microRNA. These mimics are now commercially available and promising results have been reported with systemic delivery methods using lipid and polymerbased nanoparticles [71-73]. Since these mimics do not have vector-based toxicity, they are promising tools for therapeutic treatment of tumors.

\section{Conclusions}

As described above, there have been many new technological advances to utilize microRNAs as therapeutic tools. In order to fully achieve this however, conceptual and technical issues still need to be overcome. Since microRNAs can potentially inhibit many genes, a major hurdle to overcome is specificity. Partial complimentarity can lead to off-target gene silencing or up-regulation and thus undesired biological effects. Given the multi-gene targets of a single microRNA, the magnitude of an off-target association may be quite large. Thus, it remains important to comprehensively evaluate each specific microRNAmediated therapy. Conversely, it may be useful to target multiple members of a gene family with a single microRNA. Such strategies are currently underway to design small multiple target artificial (SMART) microRNAs to simultaneously target members of a single gene family, such as E2F [74]. A more thorough understanding of microRNA biology and function will allow for more suitable strategies. Another issue that warrants future study is the efficiency of delivery of microRNA to specific sites. One needs to achieve a certain amplitude of target gene modulation and to maximize the number of cells that receive therapeutic microRNA at target sites. This effect also needs to be long-lasting with minimal toxicity to the recipient. Further advances in the area of drug delivery will no doubt improve upon the current tools of the trade.

Once a provocative finding in a worm-based model, microRNAs have now become a grand player in the field of biological science and clinical therapy. Research within the last few decades has significantly added to our knowledge of the biogenesis and function of microRNAs. These studies have shown that microRNAs play a large and key role in many aspects of cancer biology and that alteration of their expression can have profound effects on cancer phenotypes. The translation of these findings to in-vivo models and clinical studies will unquestionably lead to greater insight into their utility in clinical settings. The notion of microRNAs as therapeutic agents is in the first phases and is at the cusp of providing major advances in research and to enhancing the tools available to alleviate cancer.

\section{Acknowledgements}

This work was supported in part by the Intramural Research Program of the Center for Cancer Research, the US National Cancer Institute.

\section{Authors' contributions}

A.B. wrote the review; J.J. and X.W.W. provided constructive review of manuscript. All authors have read and approved the final manuscript.

\section{Competing interests}

The authors declare that they have no competing interests.

Received: 15 September 2010 Accepted: 6 October 2010 Published: 6 October 2010

\section{References}

1. Bartel DP: MicroRNAs: genomics, biogenesis, mechanism, and function. Cell 2004, 116:281-297.

2. Liu CG, Calin GA, Meloon B, Gamliel N, Sevignani C, Ferracin M, Dumitru CD, Shimizu M, Zupo S, Dono M, et al: An oligonucleotide microchip for genome-wide microRNA profiling in human and mouse tissues. Proc Natl Acad Sci USA 2004, 101:9740-9744

3. Schmittgen TD, Lee EJ, Jiang J, Sarkar A, Yang L, Elton TS, Chen C: Realtime PCR quantification of precursor and mature microRNA. Methods 2008, 44:31-38

4. Schmittgen TD, Jiang J, Liu Q, Yang L: A high-throughput method to monitor the expression of microRNA precursors. Nucleic Acids Res 2004, 32:e43.

5. Chen X, Ba Y, Ma L, Cai X, Yin Y, Wang K, Guo J, Zhang Y, Chen J, Guo X, et al: Characterization of microRNAs in serum: a novel class of biomarkers for diagnosis of cancer and other diseases. Cell Res 2008, 18:997-1006.

6. Deng S, Calin GA, Croce CM, Coukos G, Zhang L: Mechanisms of microRNA deregulation in human cancer. Cell Cycle 2008, 7:2643-2646.

7. Conrad R, Barrier M, Ford LP: Role of microRNA and microRNA processing factors in development and disease. Birth Defects Res C Embryo Today 2006, 78:107-117. 
8. Schmittgen TD: Regulation of microRNA processing in development, differentiation and cancer. J Cell Mol Med 2008, 12:1811-1819.

9. Thomson JM, Newman M, Parker JS, Morin-Kensicki EM, Wright T, Hammond SM: Extensive post-transcriptional regulation of microRNAs and its implications for cancer. Genes Dev 2006, 20:2202-2207.

10. Calin GA, Ferracin M, Cimmino A, Di Leva G, Shimizu M, Wojcik SE, lorio MV, Visone R, Sever NI, Fabbri M, et al: A MicroRNA signature associated with prognosis and progression in chronic lymphocytic leukemia. $N$ Engl J Med 2005, 353:1793-1801.

11. Calin GA, Liu CG, Sevignani C, Ferracin M, Felli N, Dumitru CD, Shimizu M, Cimmino A, Zupo S, Dono $M$, et al: MicroRNA profiling reveals distinct signatures in B cell chronic lymphocytic leukemias. Proc Natl Acad Sci USA 2004, 101:11755-11760.

12. Metzler M, Wilda M, Busch $K$, Viehmann $S$, Borkhardt A: High expression of precursor microRNA-155/BIC RNA in children with Burkitt lymphoma. Genes Chromosomes Cancer 2004, 39:167-169.

13. Takamizawa J, Konishi H, Yanagisawa K, Tomida S, Osada H, Endoh H, Harano T, Yatabe $Y$, Nagino M, Nimura $Y$, et al: Reduced expression of the let-7 microRNAs in human lung cancers in association with shortened postoperative survival. Cancer Res 2004, 64:3753-3756.

14. Michael MZ, O'Connor SM, Holst Pellekaan NG, Young GP, James RJ: Reduced accumulation of specific microRNAs in colorectal neoplasia. Mol Cancer Res 2003, 1:882-891.

15. Iorio MV, Ferracin M, Liu CG, Veronese A, Spizzo R, Sabbioni S, Magri E, Pedriali M, Fabbri M, Campiglio M, et al: MicroRNA gene expression deregulation in human breast cancer. Cancer Res 2005, 65:7065-7070.

16. Calin GA, Dumitru CD, Shimizu M, Bichi R, Zupo S, Noch E, Aldler H, Rattan S, Keating M, Rai K, et al: Frequent deletions and down-regulation of micro-RNA genes miR15 and miR16 at 13q14 in chronic lymphocytic leukemia. Proc Natl Acad Sci USA 2002, 99:15524-15529.

17. Sonoki T, Iwanaga $\mathrm{E}$, Mitsuya $\mathrm{H}$, Asou N: Insertion of microRNA-125b-1, a human homologue of lin-4, into a rearranged immunoglobulin heavy chain gene locus in a patient with precursor B-cell acute lymphoblastic leukemia. Leukemia 2005, 19:2009-2010.

18. Cimmino A, Calin GA, Fabbri M, lorio MV, Ferracin M, Shimizu M, Wojcik SE, Aqeilan Rl, Zupo S, Dono M, et al: miR-15 and miR-16 induce apoptosis by targeting BCL2. Proc Natl Acad Sci USA 2005, 102:13944-13949.

19. Chan JA, Krichevsky AM, Kosik KS: MicroRNA-21 is an antiapoptotic factor in human glioblastoma cells. Cancer Res 2005, 65:6029-6033.

20. Lu J, Getz G, Miska EA, Alvarez-Saavedra E, Lamb J, Peck D, SweetCordero A, Ebert BL, Mak RH, Ferrando AA, et al: MicroRNA expression profiles classify human cancers. Nature 2005, 435:834-838.

21. Volinia S, Calin GA, Liu CG, Ambs S, Cimmino A, Petrocca F, Visone R, lorio $\mathrm{M}$, Roldo $\mathrm{C}$, Ferracin $\mathrm{M}$, et al: A microRNA expression signature of human solid tumors defines cancer gene targets. Proc Natl Acad Sci USA 2006, 103:2257-2261.

22. Johnson $S M$, Grosshans $H$, Shingara J, Byrom M, Jarvis R, Cheng A Labourier E, Reinert KL, Brown D, Slack FJ: RAS is regulated by the let-7 microRNA family. Cell 2005, 120:635-647.

23. Hayashita Y, Osada H, Tatematsu Y, Yamada H, Yanagisawa K, Tomida S, Yatabe $Y$, Kawahara K, Sekido $Y$, Takahashi T: A polycistronic microRNA cluster, miR-17-92, is overexpressed in human lung cancers and enhances cell proliferation. Cancer Res 2005, 65:9628-9632.

24. Meng $F$, Henson $R$, Lang M, Wehbe $H$, Maheshwari S, Mendell JT, Jiang J, Schmittgen TD, Patel T: Involvement of human micro-RNA in growth and response to chemotherapy in human cholangiocarcinoma cell lines. Gastroenterology 2006, 130:2113-2129.

25. Volinia S, Calin GA, Liu CG, Ambs S, Cimmino A, Petrocca F, Visone R, lorio $\mathrm{M}$, Roldo C, Ferracin M, et al: A microRNA expression signature of human solid tumors defines cancer gene targets. Proc Natl Acad Sci USA 2006, 103:2257-2261.

26. Ambros V: MicroRNA pathways in flies and worms: growth, death, fat, stress, and timing. Cell 2003, 113:673-676.

27. Tong AW, Nemunaitis J: Modulation of microRNA activity in human cancer: a new paradigm for cancer gene therapy? Cancer Gene Ther 2008, 15:341-355.

28. Chang TC, Wentzel EA, Kent OA, Ramachandran K, Mullendore M, Lee KH, Feldmann G, Yamakuchi M, Ferlito M, Lowenstein CJ, et al: Transactivation of miR-34a by p53 broadly influences gene expression and promotes apoptosis. Mol Cell 2007, 26:745-752.
29. Chiyomaru T, Enokida H, Tatarano S, Kawahara K, Uchida Y, Nishiyama K, Fujimura L, Kikkawa N, Seki N, Nakagawa M: miR-145 and miR-133a function as tumour suppressors and directly regulate FSCN1 expression in bladder cancer. Br J Cancer 2010, 102:883-891.

30. Lee $Y$, Yang X, Huang Y, Fan H, Zhang Q, Wu Y, Li J, Hasina R, Cheng C, Lingen MW, et al: Network modeling identifies molecular functions targeted by miR-204 to suppress head and neck tumor metastasis. PLoS Comput Biol 2010, 6:e1000730.

31. Gramantieri L, Ferracin M, Fornari F, Veronese A, Sabbioni S, Liu CG, Calin GA, Giovannini C, Ferrazzi E, Grazi GL, et al: Cyclin G1 is a target of miR-122a, a microRNA frequently down-regulated in human hepatocellular carcinoma. Cancer Res 2007, 67:6092-6099.

32. Gramantieri L, Fornari F, Ferracin M, Veronese A, Sabbioni S, Calin GA, Grazi GL, Croce CM, Bolondi L, Negrini M: MicroRNA-221 targets Bmf in hepatocellular carcinoma and correlates with tumor multifocality. Clin Cancer Res 2009, 15:5073-5081.

33. Song B, Wang C, Liu J, Wang X, Lv L, Wei L, Xie L, Zheng Y, Song X: MicroRNA-21 regulates breast cancer invasion partly by targeting tissue inhibitor of metalloproteinase 3 expression. J Exp Clin Cancer Res 2010, 29:29.

34. Favaro E, Ramachandran A, McCormick R, Gee H, Blancher C, Crosby M, Devlin C, Blick C, Buffa F, Li JL, et al: MicroRNA-210 regulates mitochondrial free radical response to hypoxia and krebs cycle in cancer cells by targeting iron sulfur cluster protein ISCU. PLOS ONE 2010, 5 : e10345.

35. McCormick R, Buffa FM, Ragoussis J, Harris AL: The Role of Hypoxia Regulated microRNAs in Cancer. Curr Top Microbiol Immunol 2010.

36. Cascio S, D'Andrea A, Ferla R, Surmacz E, Gulotta E, Amodeo V, Bazan V, Gebbia N, Russo A: miR-20b modulates VEGF expression by targeting HIF-1 alpha and STAT3 in MCF-7 breast cancer cells. J Cell Physiol 2010, 224:242-249.

37. Calin GA, Croce CM: MicroRNA signatures in human cancers. Nat Rev Cancer 2006, 6:857-866.

38. Blenkiron C, Miska EA: microRNAs in cancer: approaches, aetiology, diagnostics and therapy. Hum Mol Genet 2007, 16(Spec No 1):R106-R113.

39. Hoshida Y, Villanueva A, Kobayashi M, Peix J, Chiang DY, Camargo A, Gupta S, Moore J, Wrobel MJ, Lerner J, et al: Gene Expression in Fixed Tissues and Outcome in Hepatocellular Carcinoma. N Engl J Med 2008.

40. Yanaihara N, Caplen N, Bowman E, Seike M, Kumamoto K, Yi M, Stephens RM, Okamoto A, Yokota J, Tanaka T, et al: Unique microRNA molecular profiles in lung cancer diagnosis and prognosis. Cancer Cell 2006, 9:189-198.

41. Schetter AJ, Leung SY, Sohn JJ, Zanetti KA, Bowman ED, Yanaihara N, Yuen ST, Chan TL, Kwong DL, Au GK, et al: MicroRNA expression profiles associated with prognosis and therapeutic outcome in colon adenocarcinoma. JAMA 2008, 299:425-436.

42. Garzon R, Volinia S, Liu CG, Fernandez-Cymering C, Palumbo T, Pichiorri F, Fabbri M, Coombes K, Alder H, Nakamura T, et al: MicroRNA signatures associated with cytogenetics and prognosis in acute myeloid leukemia. Blood 2008, 111:3183-3189.

43. Ji J, Wang XW: New kids on the block: Diagnostic and prognostic microRNAs in hepatocellular carcinoma. Cancer Biol Ther 2009, 8 .

44. Jiang J, Gusev Y, Aderca I, Mettler TA, Nagorney DM, Brackett DJ, Roberts LR, Schmittgen TD: Association of MicroRNA expression in hepatocellular carcinomas with hepatitis infection, cirrhosis, and patient survival. Clin Cancer Res 2008, 14:419-427.

45. Chung GE, Yoon JH, Myung SJ, Lee JH, Lee SH, Lee SM, Kim SJ, Hwang SY, Lee HS, Kim CY: High expression of microRNA-15b predicts a low risk of tumor recurrence following curative resection of hepatocellular carcinoma. Oncol Rep 2010, 23:113-119.

46. Budhu A, Jia HL, Forgues M, Liu CG, Goldstein D, Lam A, Zanetti KA, Ye QH, Qin LX, Croce CM, et al: Identification of metastasis-related microRNAs in hepatocellular carcinoma. Hepatology 2008, 47:897-907.

47. Coulouarn C, Factor VM, Andersen JB, Durkin ME, Thorgeirsson SS: Loss of miR-122 expression in liver cancer correlates with suppression of the hepatic phenotype and gain of metastatic properties. Oncogene 2009 28:3526-3536.

48. Huang Q, Gumireddy K, Schrier M, le Sage C, Nagel R, Nair S, Egan DA, Li A, Huang G, Klein-Szanto AJ, et al: The microRNAs miR-373 and miR-520c promote tumour invasion and metastasis. Nat Cell Biol 2008, 10:202-210. 
49. Negrini M, Calin GA: Breast cancer metastasis: a microRNA story. Breast Cancer Res 2008, 10:203.

50. Tavazoie SF, Alarcon C, Oskarsson T, Padua D, Wang Q, Bos PD, Gerald WL, Massague J: Endogenous human microRNAs that suppress breast cancer metastasis. Nature 2008, 451:147-152.

51. Huang YS, Dai Y, Yu XF, Bao SY, Yin YB, Tang M, Hu CX: Microarray analysis of microRNA expression in hepatocellular carcinoma and non-tumorous tissues without viral hepatitis. J Gastroenterol Hepatol 2008, 23:87-94.

52. Murakami Y, Yasuda T, Saigo K, Urashima T, Toyoda H, Okanoue T, Shimotohno K: Comprehensive analysis of microRNA expression patterns in hepatocellular carcinoma and non-tumorous tissues. Oncogene 2006, 25:2537-2545

53. Ji J, Shi J, Budhu A, Yu Z, Forgues M, Roessler S, Ambs S, Chen Y, Meltzer PS, Croce CM, et al: MicroRNA expression, survival, and response to interferon in liver cancer. N Engl J Med 2009, 361:1437-1447.

54. Weiler J, Hunziker J, Hall J: Anti-microRNA oligonucleotides (AMOs): ammunition to target microRNAs implicated in human disease? Gene Ther 2006, 13:496-502.

55. Baker BF, Lot SS, Condon TP, Cheng-Flournoy S, Lesnik EA, Sasmor HM, Bennett CF: 2'-O-(2-Methoxy)ethyl-modified anti-intercellular adhesion molecule 1 (ICAM-1) oligonucleotides selectively increase the ICAM-1 mRNA level and inhibit formation of the ICAM-1 translation initiation complex in human umbilical vein endothelial cells. J Biol Chem 1997, 272:11994-12000.

56. Si ML, Zhu S, Wu H, Lu Z, Wu F, Mo YY: miR-21-mediated tumor growth. Oncogene 2007, 26:2799-2803.

57. Esau C, Davis S, Murray SF, Yu XX, Pandey SK, Pear M, Watts L, Booten SL, Graham M, McKay R, et al: miR-122 regulation of lipid metabolism revealed by in vivo antisense targeting. Cell Metab 2006, 3:87-98

58. Stenvang J, Silahtaroglu AN, Lindow M, Elmen J, Kauppinen S: The utility of LNA in microRNA-based cancer diagnostics and therapeutics. Semin Cancer Biol 2008, 18:89-102.

59. Corsten MF, Miranda R, Kasmieh R, Krichevsky AM, Weissleder R, Shah K: MicroRNA-21 knockdown disrupts glioma growth in vivo and displays synergistic cytotoxicity with neural precursor cell delivered S-TRAIL in human gliomas. Cancer Res 2007, 67:8994-9000.

60. Ebert MS, Neilson JR, Sharp PA: MicroRNA sponges: competitive inhibitors of small RNAs in mammalian cells. Nat Methods 2007, 4:721-726.

61. Xiao J, Yang B, Lin H, Lu Y, Luo X, Wang Z: Novel approaches for genespecific interference via manipulating actions of microRNAs: examination on the pacemaker channel genes HCN2 and HCN4. J Cell Physiol 2007, 212:285-292.

62. Choi WY, Giraldez AJ, Schier AF: Target protectors reveal dampening and balancing of Nodal agonist and antagonist by miR-430. Science 2007, 318:271-274.

63. Gumireddy K, Young DD, Xiong X, Hogenesch JB, Huang Q, Deiters A: Small-molecule inhibitors of microrna miR-21 function. Angew Chem Int Ed Eng/ 2008, 47:7482-7484

64. Chung KH, Hart CC, Al-Bassam S, Avery A, Taylor J, Patel PD, Vojtek AB, Turner DL: Polycistronic RNA polymerase II expression vectors for RNA interference based on BIC/miR-155. Nucleic Acids Res 2006, 34:e53.

65. Stegmeier F, Hu G, Rickles RJ, Hannon GJ, Elledge SJ: A lentiviral microRNA-based system for single-copy polymerase II-regulated RNA interference in mammalian cells. Proc Natl Acad Sci USA 2005, 102:13212-13217.

66. Ji Q, Hao X, Meng Y, Zhang M, Desano J, Fan D, Xu L: Restoration of tumor suppressor miR-34 inhibits human p53-mutant gastric cancer tumorspheres. BMC Cancer 2008, 8:266.

67. Yu F, Yao H, Zhu P, Zhang X, Pan Q, Gong C, Huang Y, Hu X, Su F, Lieberman J, et al: let-7 regulates self renewal and tumorigenicity of breast cancer cells. Cell 2007, 131:1109-1123.

68. Cimmino A, Calin GA, Fabbri M, lorio MV, Ferracin M, Shimizu M, Wojcik SE, Aqeilan Rl, Zupo S, Dono M, et al: miR-15 and miR-16 induce apoptosis by targeting BCL2. Proc Natl Acad Sci USA 2005, 102:13944-13949.

69. Bonci D, Coppola V, Musumeci M, Addario A, Giuffrida R, Memeo L, D'Urso L, Pagliuca A, Biffoni M, Labbaye C, et al: The miR-15a-miR-16-1 cluster controls prostate cancer by targeting multiple oncogenic activities. Nat Med 2008, 14:1271-1277.

70. Kota J, Chivukula RR, O'donnell KA, Wentzel EA, Montgomery CL, Hwang HW, Chang TC, Vivekanandan P, Torbenson M, Clark KR, et al:
Therapeutic microRNA delivery suppresses tumorigenesis in a murine liver cancer model. Cell 2009, 137:1005-1017.

71. Landen CN Jr, Chavez-Reyes A, Bucana C, Schmandt R, Deavers MT, LopezBerestein G, Sood AK: Therapeutic EphA2 gene targeting in vivo using neutral liposomal small interfering RNA delivery. Cancer Res 2005, 65:6910-6918.

72. Merritt WM, Lin YG, Spannuth WA, Fletcher MS, Kamat AA, Han LY, Landen CN, Jennings N, De GK, Langley RR, et al: Effect of interleukin-8 gene silencing with liposome-encapsulated small interfering RNA on ovarian cancer cell growth. J Natl Cancer Inst 2008, 100:359-372.

73. Akinc A, Zumbuehl A, Goldberg M, Leshchiner ES, Busini V, Hossain N, Bacallado SA, Nguyen DN, Fuller J, Alvarez R, et al: A combinatorial library of lipid-like materials for delivery of RNAi therapeutics. Nat Biotechnol 2008, 26:561-569.

74. De GV, Caron M, Scott N, Menard C, Gaumont-Leclerc MF, Chartrand P, Major F, Ferbeyre G: Designing small multiple-target artificial RNAs. Nucleic Acids Res 2010.

75. Zhu S, Wu H, Wu F, Nie D, Sheng S, Mo YY: MicroRNA-21 targets tumor suppressor genes in invasion and metastasis. Cell Res 2008, 18:350-359.

76. Lowery AJ, Miller N, McNeill RE, Kerin MJ: MicroRNAs as prognostic indicators and therapeutic targets: potential effect on breast cancer management. Clin Cancer Res 2008, 14:360-365.

77. Bandres E, Cubedo E, Agirre X, Malumbres R, Zarate R, Ramirez N, Abajo A, Navarro A, Moreno I, Monzo M, et al: Identification by Real-time PCR of 13 mature microRNAs differentially expressed in colorectal cancer and nontumoral tissues. Mol Cancer 2006, 5:29.

78. Cummins JM, He Y, Leary RJ, Pagliarini R, Diaz LA Jr, Sjoblom T, Barad O, Bentwich Z, Szafranska AE, Labourier E, et al: The colorectal microRNAome. Proc Natl Acad Sci USA 2006, 103:3687-3692.

79. Tazawa H, Tsuchiya N, Izumiya M, Nakagama H: Tumor-suppressive miR34a induces senescence-like growth arrest through modulation of the E2F pathway in human colon cancer cells. Proc Natl Acad Sci USA 2007, 104:15472-15477.

80. Spizzo R, Nicoloso MS, Croce CM, Calin GA: SnapShot: MicroRNAs in Cancer. Cell 2009, 137:586.

81. Eder M, Scherr M: MicroRNA and lung cancer. N Engl J Med 2005, 352:2446-2448.

82. Bloomston M, Frankel WL, Petrocca F, Volinia S, Alder H, Hagan JP, Liu CG, Bhatt D, Taccioli C, Croce CM: MicroRNA expression patterns to differentiate pancreatic adenocarcinoma from normal pancreas and chronic pancreatitis. JAMA 2007, 297:1901-1908.

83. Lee EJ, Gusev Y, Jiang J, Nuovo GJ, Lerner MR, Frankel WL, Morgan DL, Postier RG, Brackett DJ, Schmittgen TD: Expression profiling identifies microRNA signature in pancreatic cancer. Int J Cancer 2007, 120:1046-1054.

84. Roldo C, Missiaglia E, Hagan JP, Falconi M, Capelli P, Bersani S, Calin GA, Volinia S, Liu CG, Scarpa A, et al: MicroRNA expression abnormalities in pancreatic endocrine and acinar tumors are associated with distinctive pathologic features and clinical behavior. J Clin Oncol 2006, 24:4677-4684.

85. Mattie MD, Benz CC, Bowers J, Sensinger K, Wong L, Scott GK, Fedele V, Ginzinger D, Getts R, Haqq C: Optimized high-throughput microRNA expression profiling provides novel biomarker assessment of clinical prostate and breast cancer biopsies. Mol Cancer 2006, 5:24.

86. Ambs S, Prueitt RL, Yi M, Hudson RS, Howe TM, Petrocca F, Wallace TA, Liu CG, Volinia S, Calin GA, et al: Genomic profiling of microRNA and messenger RNA reveals deregulated microRNA expression in prostate cancer. Cancer Res 2008, 68:6162-6170.

87. Iorio MV, Visone R, Di LG, Donati V, Petrocca F, Casalini P, Taccioli C, Volinia S, Liu CG, Alder $\mathrm{H}$, et al: MicroRNA signatures in human ovarian cancer. Cancer Res 2007, 67:8699-8707.

88. Taylor DD, Gercel-Taylor C: MicroRNA signatures of tumor-derived exosomes as diagnostic biomarkers of ovarian cancer. Gynecol Oncol 2008, 110:13-21.

89. Pineau P, Volinia S, McJunkin K, Marchio A, Battiston C, Terris B, Mazzaferro V, Lowe SW, Croce CM, Dejean A: miR-221 overexpression contributes to liver tumorigenesis. Proc Natl Acad Sci USA 2010, 107:264-269.

90. Ji J, Zhao L, Budhu A, Forgues M, Jia HL, Qin LX, Ye QH, Yu J, Shi X, Tang $Z Y$, et al: Let-7g targets collagen type I alpha2 and inhibits cell migration in hepatocellular carcinoma. J Hepatol 2010, 52:690-697. 
91. He H, Jazdzewski K, Li W, Liyanarachchi S, Nagy R, Volinia S, Calin GA, Liu CG, Franssila K, Suster $S$, et al: The role of microRNA genes in papillary thyroid carcinoma. Proc Natl Acad Sci USA 2005, 102:19075-19080.

92. Nikiforova MN, Chiosea SI, Nikiforov YE: MicroRNA expression profiles in thyroid tumors. Endocr Pathol 2009, 20:85-91.

93. Visone R, Pallante P, Vecchione A, Cirombella R, Ferracin M, Ferraro A, Volinia S, Coluzzi S, Leone V, Borbone E, et al: Specific microRNAs are downregulated in human thyroid anaplastic carcinomas. Oncogene 2007, 26:7590-7595.

94. Krutzfeldt J, Rajewsky N, Braich R, Rajeev KG, Tuschl T, Manoharan M, Stoffel M: Silencing of microRNAs in vivo with 'antagomirs'. Nature 2005, 438:685-689.

95. Bijsterbosch MK, Rump ET, De Vrueh RL, Dorland R, van VR, Tivel KL, Biessen EA, Van Berkel TJ, Manoharan M: Modulation of plasma protein binding and in vivo liver cell uptake of phosphorothioate oligodeoxynucleotides by cholesterol conjugation. Nucleic Acids Res 2000, 28:2717-2725.

96. Biisterbosch MK, Manoharan M, Dorland R, van VR, Biessen EA, Van Berkel TJ: bis-Cholesteryl-conjugated phosphorothioate oligodeoxynucleotides are highly selectively taken up by the liver. $J$ Pharmacol Exp Ther 2002, 302:619-626.

97. Wu H, Lima WF, Zhang H, Fan A, Sun H, Crooke ST: Determination of the role of the human RNase $\mathrm{H} 1$ in the pharmacology of DNA-like antisense drugs. J Biol Chem 2004, 279:17181-17189.

98. Cerritelli SM, Frolova EG, Feng C, Grinberg A, Love PE, Crouch RJ: Failure to produce mitochondrial DNA results in embryonic lethality in Rnaseh1 null mice. Mol Cell 2003, 11:807-815.

99. Elmen J, Lindow M, Schutz S, Lawrence M, Petri A, Obad S, Lindholm M Hedtjarn M, Hansen HF, Berger U, et al: LNA-mediated microRNA silencing in non-human primates. Nature 2008

100. Tsuda N, Ishiyama S, Li Y, loannides CG, Abbruzzese JL, Chang DZ: Synthetic microRNA designed to target glioma-associated antigen 1 transcription factor inhibits division and induces late apoptosis in pancreatic tumor cells. Clin Cancer Res 2006, 12:6557-6564.

101. Tsuda N, Mine T, loannides CG, Chang DZ: Synthetic microRNA targeting glioma-associated antigen-1 protein. Methods Mol Biol 2009, 487:435-449.

doi:10.1186/1756-8722-3-37

Cite this article as: Budhu et al: The clinical potential of microRNAs. Journal of Hematology \& Oncology 2010 3:37.

\section{Submit your next manuscript to BioMed Central and take full advantage of:}

- Convenient online submission

- Thorough peer review

- No space constraints or color figure charges

- Immediate publication on acceptance

- Inclusion in PubMed, CAS, Scopus and Google Scholar

- Research which is freely available for redistribution

Submit your manuscript at www.biomedcentral.com/submit
Biomed Central 